Dorota STRZYŻEWSKA

IEiB WFCh UKSW Warszawa

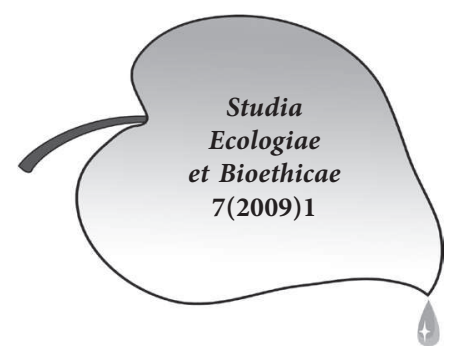

\title{
Właściwości układu oddechowego młodzieży warszawskiej a zanieczyszczenie środowiska
}

\begin{abstract}
Wstęp
Oddychanie jest jednym z najważniejszych przejawów życia. Aby było sprawne, w złożonych organizmach wykształcił się wielonarządowy system dostawy tlenu i odbioru dwutlenku węgla - układ oddechowy.

Wpływ zanieczyszczenia środowiska na zdrowie człowieka ulegał zmianom wraz z rozwojem cywilizacji (Czarnocki, 1987). Zaburzona równowaga systemu ekologicznego nie pozostała bez wpływu na prawidłowe funkcjonowanie organizmu człowieka. Szczególnie wrażliwe na tego typu zmiany środowiskowe są organizmy młode, będące w trakcie intensywnego rozwoju somatycznego (Dębska, 2000). Badania przekrojowe ludności w Europy i USA wykazały, że ekspozycja na długotrwałe średnie stężenia pyłów wywołuje obniżenie cech gazometrycznych płuc oraz kaszel. Na tego typu niebezpieczeństwo są szczególnie narażone dzieci mieszkające w okolicy dużych szlaków komunikacyjnych (Rudkowski, 2000).

Organizm ludzki posiada również pewne możliwości dostosowawcze do zanieczyszczonego środowiska, co wykazały wyniki badań przeprowadzonych na dzieciach w różnym wieku (Pyżuk i Wolański, 1972). Okazuje się, że przystosowanie do życia na obszarze o znacznym zapyleniu i intoksykacji powietrza przejawia się zwiększeniem wszystkich badanych właściwości oddechowych. Dzieci zamieszkujące tereny o największym zanieczyszczeniu powietrza miały podwyższone $\mathrm{VC} \mathrm{i} \mathrm{FEV} \mathrm{F}_{1}$, co jest właśnie pochodną procesu przystosowawczego do znacznego zapylenia i zasiarczenia powietrza atmosferycznego (Pyżuk, 1974).

Negatywny wpływ zanieczyszczenia środowiska na rozwój fizyczny dzieci potwierdziły badania w Czechosłowacji, a mianowicie dzieci zamieszkujące tereny o znacznym zanieczyszczeniu powietrza miały obniżoną wysokość i masę ciała, co wiązało się z opóźnionym rozwojem tkanki kostnej niż miało to miejsce na terenach o mniejszym zanieczyszczeniu (Chowin i Russel, 1972 - za Czarnocki, 1987).

Celem niniejszej pracy jest ocena wydolności układu oddechowego młodzieży gimnazjalnej, zamieszkującej dwa środowiska, różniące się od siebie stopniem
\end{abstract}


zanieczyszczenia powietrza. Hipoteza badawcza pracy zakłada, że wielkości cech oddechowych badanej młodzieży na terenie bardziej zanieczyszczonej dzielnicy Śródmieście będą istotnie różne niż w mniej zanieczyszczonej, bardziej zielonej i willowej dzielnicy Wawer.

\section{Material i metoda}

Badania będące podstawą niniejszej pracy przeprowadzono na młodzieży13-16 letniej, uczęszczającej do dwóch gimnazjów na terenie miasta stołecznego Warszawy, zlokalizowanych w Śródmieściu i w Międzylesiu. Wyboru dzielnic dokonano na podstawie danych dotyczących zanieczyszczenia środowiska. O wiele wyższe zanieczyszczenia środowiska ma miejsce w Dzielnicy Śródmieście niż w Dzielnicy Wawer, w której skład wchodzi Międzylesie. Dane dotyczące zanieczyszczenia tych terenów przedstawione zostały w tabeli 1 (GUS, 2007). W Śródmieściu badania przeprowadzono w gimnazjum z oddziałami dwujęzycznymi nr 42, na ulicy Twardej 8/12, natomiast w Międzylesiu wzięto pod uwagę gimnazjum z oddziałami integracyjnymi nr 103, znajdujące się na ulicy Żegańskiej la. Ogółem zbadano 219 chłopców i 225 dziewcząt, w tym ze Śródmieścia pochodziło 112 chłopców i 117 dziewcząt, natomiast z Międzylesia - 107 chłopców i 108 dziewcząt (Tab. 2). Badania były przeprowadzone od marca do czerwca 2006 roku.

Pod uwagę wzięto cechy somatyczne jaki i oddechowe. Zmierzono wysokość, masę ciała i obwód klatki piersiowej oraz osiem cech oddechowych: VC- pojemność życiowa płuc w litrach (maksymalna objętość powietrza, jaka może znajdować się w płucach badanego), MV - minutowa wentylacja płuc w litrach (ilość wydychanego powietrza w ciągu jednej minuty), $\mathrm{FEV}_{1}$ - wysiłkowa 1 sek. pojemność oddechowa płuc w litrach, RR - częstość oddechów na minutę, zwana też rytmem oddychania, TV - objętość oddechowa (ilość powietrza, jaką człowiek wprowadza do płuc podczas każdego normalnego cyklu oddechowego (wdechu i wydechu)), IRV - rezerwa tlenowa wdechowa (ilość powietrza, którą można jeszcze wprowadzić do płuc, nie licząc normalnego wdechu.), ERV - rezerwa tlenowa wydechowa (jest to możliwy dalszy wydech powietrza, który poprzedzony jest normalnym wydechem - ilość powietrza zalegająca w płucach), Ap czas bezdechu we wdechu w sekundach (jest to czas, w jakim badany po wzięciu głębokiego wdechu wytrzyma najdłużej do wydechu). Ponadto obliczono trzy wskaźniki: BMI (masę ciała w kg / wysokości ciała w m²), wskaźnik Marty, oceniający rozrost klatki piersiowej (obw. kl pier / wysokość ciała $\mathrm{w} \mathrm{cm}$ ) ${ }^{\star} 100$ oraz wskaźnik Ziemssena (VC / wysokość ciała w cm)*100.

Pomiarów somatycznych dokonano przy użyciu antropometru, wagi lekarskiej i taśmy antropometrycznej, zgodnie z metodami opisanymi w podręcznikach Wolańskiego (1975) oraz Malinowskiego i Wolańskiego (1988). Badany miał na sobie jedynie strój gimnastyczny oraz był bez obuwia. 
Cechy oddechowe zmierzono przy pomocy spirometru Welch Allyn Schiller SP-10 (wyprodukowanego w San Diego, CA, USA), zgodnie z techniką pomiarową, zawartą w instrukcji (IOS, 1998). Badani byli dokładnie przyuczani do poprawnego wykonywania każdego testu, który przeprowadzono trzykrotnie i tylko najlepszy wynik był brany pod uwagę. W czasie badania pacjent oddychał poprzez ustnik połączony specjalną rurką ze spirometrem. Na nosie znajdował się zacisk, który zabezpieczał, aby wydychane powietrze docierało tylko do aparatu pomiarowego.

Obliczeń statystycznych dokonano przy użyciu pakietu statystycznego SPSS 8.0, i programu Statistica 7.1. Do oceny różnic w średnich arytmetycznych oraz w częstościach cech kodowanych między porównywanymi terenami zastosowano test t-Studenta dla grup niezależnych.

Wielkości badanych cech pomiarowych są przestawione w punktach „Z”. Punktem wyjścia był cały badany materiał (młodzież ze Śródmieścia i Międzylesia) w podziale na płeć i grupy wieku. Od wielkości każdej cechy badanego odejmowano średnią arytmetyczną całości materiału (dla jego grupy wiekowej i płci) oraz dzielono przez SD. Punkty „z" były podstawą do oceny różnic między młodzieżą $\mathrm{z}$ dwóch porównywanych terenów.

\section{Analiza wyników własnych}

Pod względem cech somatycznych, takich jak wysokość i masa ciała, wskaźnik masywności budowy (BMI), obwód klatki piersiowej oraz jej rozrost (wskaźnik Marty) młodzież z dwóch porównywanych terenów (Międzylesia i Śródmieścia) nie różni się istotnie statystycznie (Tab. 3 i 4).

Podobnie pod względem takich cech oddechowych jak: VC, wskaźnik Ziemmsena, FEV1, ERV i RR nie stwierdzono różnic istotnych statystycznie między młodzieżą Międzylesia i Śródmieścia, a u chłopców nie stwierdzono także różnic w przypadku MV, TV (Tab. 3 i 4).

$\mathrm{W}$ przypadku obu płci różnice istotne statystycznie wystąpiły dla rezerwy tlenowej wdechowej (IRV) oraz czasu bezdechu we wdechu (Ap), które to cechy okazały się być większe u młodzieży ze Śródmieścia w porównaniu z młodzieżą z Międzylesia. Ponadto, różnice istotne statystycznie wystąpiły też u dziewcząt dla takich cech jak wentylacja minutowa (MV) i objętość oddechowa (TV), które to cechy były większe u uczennic z Międzylesia w porównaniu z ich rówieśniczkami ze Śródmieścia (Tab. 3 i 4).

\section{Dyskusja wyników}

Wyniki badań będące podstawą niniejszej pracy wykazały, że różnice w cechach somatycznych i większości cech oddechowych młodzieży z Międzylesia 
i Śródmieścia nie są istotne statystycznie. Są jednak cechy oddechowe, które takie różnice wykazują. Dziewczęta z Międzylesia (terenu mniej zanieczyszczonego) charakteryzują się większą objętością oddechową (TV) i minutową wentylacją (MV) w porównaniu z młodzieżą ze Śródmieścia (terenu bardziej zanieczyszczonego). U całej młodzieży ze Śródmieścia większa jest natomiast rezerwa zapasowa wdechowa (IRV) oraz dłuższy czas bezdechu we wdechu (Ap) niż u młodzieży Międzylesia.

Trudno odpowiedzieć na pytanie czy zjawisko większej MV i TV u dziewcząt z Międzylesia zależy od jakości wdychanego powietrza. Temat ten będzie kontynuowany w kolejnej pracy, biorącej pod uwagę szereg cech rodzinnych i tryb życia badanej młodzieży. Natomiast obserwacja dotycząca większej rezerwy wdechowej oraz dłuższego czasu bezdechu młodzieży ze Śródmieścia w porównaniu z Międzylesiem może mieć swoje uzasadnienie w stopniu zanieczyszczenia wdychanego powietrza. Większa rezerwa wdechowa (ilość powietrza, którą organizm może jeszcze wprowadzić do płuc poza normalnym wdechem) u młodzieży ze Śródmieścia, byłaby mechanizmem skutecznie doprowadzającym do płuc większą ilość powietrza (w przypadku, gdy jest ono na tyle zanieczyszczone, że ilość dostarczanego tlenu przy normalnym wdechu jest niewystarczająca). Podobnie można tłumaczyć dłuższy czas bezdechu we wdechu (Ap) u młodzieży ze Śródmieścia, który umożliwia wprowadzenie skutecznej przerwy w oddychaniu, aby chwilowo ograniczyć wdychanie zbyt nasyconego np. spalinami powietrza.

Fakt, że wielkości pewnych cech oddechowych mogą być wyższe, a innych niższe jako odpowiedź na zanieczyszczenia powietrza, wydaje się być logiczne, szczególnie, że młody organizm, broniąc się przed szkodliwym wpływem zanieczyszczeń może zwiększać lub zmniejszać rezerwy swojego organizmu (Wolanski, 2005). Wyniki wcześniejszych badań wskazują także, że przy bardzo dużym zanieczyszczeniu powietrza (np. na terenie GOP) miało miejsce podwyższenie się wszystkich właściwości układu oddechowego (Pyżuk i Wolański, 1972), co uważano jako wynik wyczerpania się rezerw organizmu. Porównanie właściwości oddechowych u ludności terenów rolniczych, uprzemysławianych i uprzemysłowionych pod koniec lat 70-tych wykazało, że najwyższe wielkości takich cech jak VC, IRV, ERV, MV oraz najniższa częstość oddechów na minutę (RR) występowały u rolniczej ludności Suwalszczyzny, zaś najmniejsze wielkości tych cech oraz częstsze oddechy spotkano na terenie uprzemysławianym, jakim było w tamtym czasie Bełchatowskie Centrum Przemysłowe (Siniarska, 1984).

Szereg badań oceniających stan układu oddechowego w zależności od zanieczyszczenia środowiska w Polsce przeprowadzono również w latach późniejszych. W latach 90-tych badania takie miały miejsce w trzech regionach województwa pomorskiego, zróżnicowanego pod względem zagrożeń środowiskowych. Wyniki wykazały negatywny wpływ zanieczyszczeń na właściwości oddechowe badanych (Judin i wsp., 2002). Inne badania przeprowadzono wśród młodych 
niepalących papierosów mężczyzn w wieku 19-23 lat, zamieszkujących różne regiony Polski (Lubiński i wsp., 2004). Wykazały one istotne obniżenie średnich wartości wskaźników czynnościowych oddychania w grupie badanych w rejonie o najwyższym stężeniu zanieczyszczeń powietrza w porównaniu do badanych w rejonie o najniższym takim wskaźniku. Badania, czy ekspozycja na zanieczyszczenie powietrza miała wpływ na czynności układu oddechowego, prowadzono również na Litwie (Strumylaite i wsp., 2001). Otrzymane wyniki wykazały obniżenie pojemności życiowej płuc (VC) oraz natężonej 1-sekundowej pojemność wydechowa (FEV1) u dzieci mieszkających na terenach o większym zanieczyszczeniu powietrza.

Niniejsze wyniki badań wykazują na brak jakiegokolwiek związku między zanieczyszczeniem powietrza a stanem rozwoju fizycznego młodzieży ze Śródmieścia i Międzylesia. Młodzież ta nie różni się pod względem wysokości i masy ciała, wskaźnika BMI, czy obwodu klatki piersiowej. Jednak badania dzieci przeprowadzone w Czechosłowacji i Stanach Zjednoczonych na terenach o wysokim stężeniu zanieczyszczeń powietrza wykazały, że występują u nich duże opóźnienia w rozwoju biologicznym, objawiające się zmniejszeniem wysokości i masy ciała oraz opóźnieniem w rozwoju tkanki kostnej (Czarnocki, 1987 - za Chowin, Russel,1972).

\section{Piśmiennictwo}

1. CzArnocki A., 1987. Zanieczyszczenie środowiska a zdrowie i możliwości rozwoju człowieka. W: Czynniki Rozwoju Człowieka, N. Wolański (red.), 416- 431, PWN, Warszawa.

2. DęвsKa U., 2000. Pułapki cywilizacji u schyłku XX wieku. W: Zagrożenia Zdrowia Dzieci i Młodzieży u Schyłku XX wieku, 17-22, praca zbiorowa, Polskie Towarzystwo Walki z Kalectwem. Oddział Wojewódzki we Wrocławiu, Wrocław.

3. GUS, 2007. Ważniejsze dane o dzielnicach miasta stołecznego Warszawa. Emisja zanieczyszczeń powietrza. W: Rocznik Statystyczny, 62-63. Zakład Wydawnictw Statystycznych GUS, Warszawa.

4. IOS, 1998. Instrukcja obsługi spirometru Welch Allyn Schiller. Welch Allyn Schiller Inc, San Diego.

5. Judin A., Uciąska R., Wysocka-Nowak E., Klicki G., Moczkowska G., Dobrzycka A., CYNowska B., Wolska-GoszKa L., 2002. Występowanie zaburzeń spirometrycznych w trzech regionach województwa pomorskiego, zróżnicowanych pod względem zagrożeń środowiskowych - doniesienia wstępne. Medycyna Środowiskowa; 5(1): 39-45.

6. Lubiński W., Frank-Piskorska A., ChciaŁowski A., PŁusa T., 2004. Wpływ zanieczyszczenia powietrza na czynności układu oddechowego u młodych mężczyzn w różnych regionach Polski. Polski Merkuriusz Lekarski; 16(92): 128-132.

7. MalinowsKi A., Wolański N., 1988. Metody badań w biologii człowieka. Wybór metod antropometrycznych. PWN, Warszawa.

8. Pyżuk M., Wolański N., 1972. Układ Oddychania i Krążenia u Dzieci w Różnych Warunkach Środowiskowych. PWN, Warszawa.

9. Pyżuk M., 1974. Rozwój Dziecka a Wrażliwość na Czynniki Środowiskowe. PWN, Warszawa. 
10. Rudkowski Z., 2000. Zdrowie dzieci w środowisku zagrożonym ekologicznie. W: Zdrowie Naszych Dzieci, praca zbiorowa, 206-207. Instytut Matki i Dziecka, Warszawa.

11. SiniarsKa A., 1984. Interpopulational and interfamilial differences in some somatic, physiological and psychomotor traits. Studies in Human Ecology, 5:195-221.

12.Strumylaite L., Kregźyte R., Dudzevicius J., Vaitkaitiene E., 2001. Air pollution and respiratory health in Kaunas Children, W: Uwarunkowania środowiskowe zdrowia dzieci, 125, Materiały X Konferencji Naukowej, Legnica.

13. Wolański N., 1975. Metody Kontroli i Normy Rozwoju Dzieci i Młodzieży. PZWL, Warszawa.

14. Wolański N., 2005. Rozwój Biologiczny Człowieka. Podstawy Auksologii, Gerontologii i Promocji Zdrowia. Wydawnictwo Naukowe PWN, Warszawa.

Tabela 1. Zanieczyszczenie powietrza na terenie całego miasta stołecznego Warszawy oraz dla dzielnic Śródmieście i Wawer

\begin{tabular}{|l|r|r|r|}
\hline \multicolumn{1}{|c|}{$\begin{array}{c}\text { Emisja zanieczyszczeń powietrza } \\
\text { w roku 2005 }\end{array}$} & \multirow{2}{*}{ Warszawa } & \multicolumn{2}{c|}{ Dzielnica } \\
\cline { 3 - 4 } & & Sródmieście & Wawer \\
\hline Zanieczyszczenie pyłowe [tona/rok] & 2350 & 1294 & 99 \\
\hline Zanieczyszczenie pyłowe na $1 \mathrm{~km}^{2}$ [tona/rok] & 4,5 & 36,6 & 1,2 \\
\hline Zanieczyszczenia gazowe ogółem [tona/rok] & 6488639 & 3438978 & 49307 \\
\hline Dwutlenek siarki[tona/rok] & 28496 & 17782 & 281 \\
\hline Tlenki azotu [tona/rok] & 9340 & 5929 & 90 \\
\hline Tlenek węgla [tona/rok] & 1382 & 507 & 79 \\
\hline Dwutlenek węgla [tona/rok] & 6448914 & 3414760 & 48857 \\
\hline $\begin{array}{l}\text { Zanieczyszczenia gazowe ogółem na } 1 \mathrm{~km}^{2} \\
\text { [tona/rok] }\end{array}$ & 12550,6 & 97146,3 & 618,7 \\
\hline
\end{tabular}

Tabela 2. Liczebność zbadanej młodzieży warszawskiej z dwóch szkót gimnazjalnych w Śródmieściu i Międzylesiu

\begin{tabular}{|c|c|c|c|c|}
\hline \multirow{2}{*}{ Wiek } & \multicolumn{2}{|c|}{ Chłopcy } & \multicolumn{2}{c|}{ Dziewczęta } \\
\cline { 2 - 5 } & $\mathbf{N}$ & $\mathbf{N}$ & $\%$ \\
\hline \multicolumn{5}{|c|}{ Warszawa-Śródmieście } \\
\hline 13 & 8 & 7.1 & 7 & 6.0 \\
\hline 14 & 35 & 31.3 & 43 & 36.8 \\
\hline 15 & 43 & 38.4 & 47 & 40.2 \\
\hline 16 & 26 & 23.2 & 20 & 17.1 \\
\hline$\Sigma$ & 112 & 100.0 & 117 & 100.0 \\
\hline \multicolumn{5}{|c|}{ Warszawa-Międzylesie } \\
\hline 13 & 5 & 4.7 & 5 & 4.6 \\
\hline 14 & 31 & 29.0 & 35 & 32.4 \\
\hline 15 & 37 & 34.6 & 35 & 30.6 \\
\hline 16 & 34 & 31.8 & 33 & 100.0 \\
\hline$\Sigma$ & 107 & 100.0 & 108 & \\
\hline
\end{tabular}


Właściwości układu oddechowego młodzieży warszawskiej a zanieczyszczenie środowiska

Tabela 3. Wielkości badanych cech somatycznych i oddechowych w punktach „z” chłopców badanych w gimnazjum w Śródmieściu i Międzylesiu

\begin{tabular}{|l|c|c|c|c|c|}
\hline \multirow{2}{*}{$\begin{array}{l}\text { Wielkość badanej } \\
\text { cechy u chłopców }\end{array}$} & \multicolumn{2}{|c|}{$\begin{array}{c}\text { Warszawa- } \\
\text { Sródmieście } \\
\text { N= 112 }\end{array}$} & \multicolumn{2}{c|}{$\begin{array}{c}\text { Warszawa- } \\
\text { Międzylesie } \\
\text { N= 103 }\end{array}$} & \multirow{2}{*}{ T- Studenta } \\
\cline { 2 - 5 } & Średnia & SD & Średnia & SD & \\
\hline Wysokość ciała & $-0,03$ & 1,03 & 0,03 & 0,96 & $t=-0,390 ; p=0,697$ \\
\hline Masa ciała & 0,02 & 1,08 & -0.02 & 0,09 & $t=0,314 ; p=0,753$ \\
\hline BMI & 0,05 & 1,11 & $-0,05$ & 0,86 & $t=0,766 ; p=0,444$ \\
\hline Obw.kl. piersiowej & 0,08 & 1,09 & $-0,09$ & 0,88 & $t=1,291 ; p=0,198$ \\
\hline Wskaźnik Marty & 0,09 & 1,05 & $-0,10$ & 0,92 & $t=1,416 ; p=0,158$ \\
\hline VC & 0,05 & 1,00 & $-0,05$ & 0,98 & $t=0,783 ; p=0,434$ \\
\hline Wskaźnik Ziemssena & 0,07 & 1,00 & $-0,08$ & 0,99 & $t=1,104 ; p=0,271$ \\
\hline MV & $-0,09$ & 0,90 & 0,09 & 1,08 & $t=1,349 ; p=0,179$ \\
\hline TV & $-0,04$ & 0,99 & 0,05 & 0,99 & $t=0,714 ; p=0,476$ \\
\hline FEV1 & 0,06 & 1,04 & $-0,05$ & 0,95 & $t=0,806 ; p=0,421$ \\
\hline IRV & 0,20 & 0,94 & $-0,21$ & 1,02 & $t=3,050 ; p=0,003^{* *}$ \\
\hline ERV & 0,02 & 1,04 & $-0,02$ & 0,96 & $t=0,309 ; p=0,758$ \\
\hline RR & $-0,03$ & 0,96 & 0,03 & 1,03 & $t=0,392 ; p=0,696$ \\
\hline AP & 0,25 & 1,00 & $-0,48$ & 0,83 & $t=5,793 ; p=0,000^{* * *}$ \\
\hline
\end{tabular}

Legenda: $\mathrm{N}$ - liczebność; SD - odchylenie standardowe; $\mathrm{T}$ - t- studenta; $\mathrm{p}$ - prawdopodobieństwo; ${ }^{*}-\mathrm{p}<0,05 ;{ }^{* *}-\mathrm{p}<0,01 ;{ }^{* *}-\mathrm{p}<0,00$

Tabela 4. Wielkości badanych cech somatycznych i oddechowych $w$ punktach „z” dziewcząt badanych w gimnazjum w Śródmieściu i Międzylesiu

\begin{tabular}{|l|c|c|c|c|c|}
\hline \multirow{2}{*}{$\begin{array}{l}\text { Wielkość badanej } \\
\text { cechy u dziewcząt }\end{array}$} & \multicolumn{2}{|c|}{$\begin{array}{c}\text { Warszawa-Śródmieście } \\
\text { N= 117 }\end{array}$} & \multicolumn{2}{c|}{$\begin{array}{c}\text { Warszawa-Międzylesie } \\
\text { N= 108 }\end{array}$} & \multirow{2}{*}{ T- Studenta } \\
\cline { 2 - 5 } & Średnia & SD & Średnia & SD & \\
\hline Wysokość ciała & & & & & \\
\hline Masa ciała & 0,03 & 0,97 & $-0,03$ & 1,02 & $\mathrm{t}=0,446 ; \mathrm{p}=0,656$ \\
\hline BMI & 0,00 & 0,99 & 0,00 & 1,00 & $\mathrm{t}=0,018 ; \mathrm{p}=0,986$ \\
\hline Obw.kl. piersiowej & 0,01 & 0,95 & $-0,02$ & 1,04 & $\mathrm{t}=0,217 ; \mathrm{p}=0,828$ \\
\hline Wskaźnik Marty & $-0,02$ & 0,95 & 0,02 & 1,04 & $\mathrm{t}=0,240 ; \mathrm{p}=0,810$ \\
\hline VC & 0,02 & 1,05 & $-0,03$ & 0,93 & $\mathrm{t}=0,447 ; \mathrm{p}=0,665$ \\
\hline Wskaźnik Ziemssenannnnn & 0,01 & 1,06 & $-0,01$ & 0,93 & $\mathrm{t}=0,195 ; \mathrm{p}=0,846$ \\
\hline MV & $-0,15$ & 0,84 & 0,16 & 1,12 & $\mathrm{t}=2,349 ; \mathrm{p}=0,020^{* *}$ \\
\hline TV & $-0,16$ & 0,82 & 0,18 & 1,15 & $\mathrm{t}=-2,505 ; \mathrm{p}=0,013^{* *}$ \\
\hline FEV1 & 0,03 & 1,02 & $-0,03$ & 0,93 & $\mathrm{t}=0,474 ; \mathrm{p}=0,636$ \\
\hline IRV & 0,16 & 1,10 & $-0,18$ & 0,85 & $\mathrm{t}=2,614 ; \mathrm{p}=0,010^{* *}$ \\
\hline ERV & 0,06 & 1,03 & $-0,06$ & 0,96 & $\mathrm{t}=0,901 ; \mathrm{p}=0,369$ \\
\hline RR & $-0,02$ & 0,84 & 0,02 & 1,03 & $\mathrm{t}=0,282 ; \mathrm{p}=0,778$ \\
\hline AP & 0,73 & 1,40 & $-0,18$ & 0,91 & $\mathrm{t}=5,597 ; \mathrm{p}=0,000^{* * *}$ \\
\hline
\end{tabular}

Legenda jak w tab. 3. 


\title{
Respiratory functions of Warsaw children and air pollution
}

\begin{abstract}
SUMMARY
This work presents studies on secondary school children inhabiting two regions of Warsaw: Śródmieście (Central part) and Międzylesie (East part). These two locations significantly differ according to air pollution, which is much higher in Śródmieście than in Międzylesie. The sample consist of 219 boys and 225 girls aged 13-16 years. The main aim of this work concerns the evaluation of physical development (body height and weight, BMI and chest circumference, Marty index - chest circ./height) and respiratory parameters (VC, Ziemssen index - VC/height, $\mathrm{MV}, \mathrm{FEV}_{1} \mathrm{RR}, \mathrm{TV}, \mathrm{IRV}, \mathrm{ERV}$, Ap) of studied children depending on the place of residence. The data were presented in " $\mathrm{z}$ " scores and the difference was calculated using $\mathrm{t}$-test for independent samples. The results show that there were not significant differences in body build as well as in most respiratory functions between children from the Central and East parts of Warsaw. The significant differences were found for IRV and Ap which were greater in children from Śódmieście and for TV and MV which were greater in girls from Międzylesie. The more detailed analysis of these studies, including data concerning living conditions of studied children and smoking habits within their families is under preparation.
\end{abstract}

